DE DE GRUYTER OPEN
Research Article

(C) 2018 Risna Resnawaty and Rivani. This is an open access article licensed under the Creative Commons Attribution-NonCommercial-NoDerivs License (http://creativecommons.org/licenses/by-nc-nd/3.0/).

\title{
Empowered Community vs Dependent Community: Corporate Social Responsibility (CSR) Implications by Mining Companies in South Sumatra Province
}

\author{
Risna Resnawaty \\ Lecturer at Department of Social Welfare, \\ Padjadjaran University
}

Rivani

Lecturer at Department of Business Administration, Padjadjaran University

Doi: $10.2478 / m j s s-2018-0098$

\begin{abstract}
Mining business actors have an obligation to maintain the sustainability of the surrounding environment, both in the physical and the social environment. Coal mining extraction activities are closely related to the exploration and exploitation of natural resources. This activity is in contact with the interests of the surrounding community, in particular with the negative impact caused. Mining companies in Indonesia are bound by the Mineral and Coal Mining Act no. 4 of 2009 to carry out community development and empowerment. Under the law, the companies are required to implement Corporate Social Responsibility (CSR). Through the implementation of CSR is expected the company can provide a positive change for the survival of communities around the mining area. PT BARA is one of mining companies that had been implementing CSR since 1983. As a state-owned company PT. BARA has various binding regulations in the implementation of CSR. The regulation comes from the central government as well as the local government in which PT. BARA does its mining business. Every year PT BARA releases an enormous amount of CSR funds, but the surrounding community is still in a state of poverty. It turns out that the problem does not stop on poverty at all. The community becomes very dependent on the company's assistance. The purpose of the CSR program is to develop and empower the community has not been able to achieve the goal. This dependence is caused by various reasons such as CSR policies of companies as well as government and CSR implementation on society.
\end{abstract}

Keyword: Corporate Social Responsibility, Community Development, Community Empowerment

\section{Introduction}

The dynamics that occur in the coal mining sector are not solely related to business problems. Fatah (2008), Prayogo (2011) stated that mining industry often triggers social conflict between society and company caused by welfare gap between the society and the company. Communities directly or indirectly impacted by the mining exploration and exploitation experience the unequal distribution of welfare. So far, people are only affected by the negative implications of the mine without getting the positive impact directly.

The presence of mining companies for the purpose of business profits often clashes with the interests of the surrounding community. Further, Evans (1988), Yakoveleva (2008), Prayogo (2011) argued that the relationship between industry and society, both to national and local communities, 
received a sharp spotlight due to the number of negative impacts caused by presence and mining activities. Based on this, Hecter (2003) stated that the mining business is not only related to taking care of the big and small profits but also creating the social legitimacy of the business world in relation to society in general.

In general, the major players in the mining business are tangible investors of state-owned companies or foreign companies that in fact come from outside the region. The existence of companies that reap huge profits from the exploitation of natural resources boosts the level of welfare for employees of the company. While local communities living around the mining industry are only displaced by social changes that occur due to shifts in the well-being of the company and its employees. The community is only being a spectator in his own country which causes a very noticeable gap between companies and society. The vast social gap has the potential for social conflict. On the other hand, companies are grazing natural resources in their ancestral lands to achieve production targets and get the most profit. If there is a conflict between the two, then all parties will swallow huge losses, not only the company but also society and country.

CSR program is one of the efforts to bridging gap and jealousy between the communities living around to the company. During this time some mining companies have conducted various CSR programs to the surrounding community. However, as the program continues the gap and jealousy of the community towards the company continue to occur even trigger a variety of conflicts that lead to the injustice of welfare distribution, ranging from land disputes, labor conflicts, and other conflicts. Related to this matter one of coal mining business actor that is PT. BARA located in Muara Enim District, South Sumatra Province, in January of 2013 has experienced two demonstrations from the surrounding community (Source: BeritaAnda.com January 16, 2013).

The welfare gap causes the phenomenon of public jealousy. In some areas in Indonesia such as Kalimantan and Sumatra, almost the same problem happened. Companies and employees live well, while the residents in the vicinity of the mine are in a state of poverty. The data suggest that in 2009 , there were about $48.25 \%$ of the poor in East Kalimantan mostly located in coal mining areas. Of the 203,156 villagers, there are 90,025 poor people. Citizens in East-Kutai (one of sub-district of East Kalimantan), 77 villages of 135 villages, are still not getting electricity (Source: korankaltim.com, December, $12^{\text {th }} 2014$ ). Another case in the province of South Sumatra that has a wealth of natural resources, the province is included in 10 provinces with the highest poverty rate in Indonesia. Similarly, in Muara Enim district known as the largest coal-producing district in South Sumatra, this district is ranked $8^{\text {th }}$ out of 15 regencies and cities in South Sumatera Province. (Source://www.kabarsmas.com. August, $8^{\text {th }}$ 2012).

Poverty is a common problem that occurs in almost all communities living outside the mining area (called Ring 1). It is therefore expected that CSR programs conducted by mining companies can contribute to improving community empowerment and reducing poverty. In connection with government policy on CSR implementation, it is anticipated that the government together with the company can intervene to improve the welfare of the surrounding community. The real implementation of CSR activities of mining companies in Indonesia is a community development program. This program is often referred to as a form of CSR activity from private mining companies and state-owned enterprises. Implementation of community development program is expected to improve the welfare of the community, especially in accessing livelihood resources such as electricity, water, education, health and income increase. Furthermore, the company must prepare the community to face life after mining.

But during this community development is limited to naming the infrastructure development program. According to Cary (1970), community development is a series of processes, methods, programs, and movements to improve the ability and capacity of the community itself to solve the problems they face. In other words, community development does not place the community as an object of development but as an active participating subject. Community development is defined as "a movement designed to improve the standard of living of the entire community through the active participation and initiative of the community" (Brokensha and Hodge: 1969, in (2013: 150). Community Development is known as a model for intervening in society as an effort to achieve community empowerment. The real implementation of CSR conducted by mining companies in Indonesia is a community development program. 
This paper describes the implication of the implementation of CSR on the community. In connection with these objectives, in fact, each year mining companies have implemented CSR activities through community development programs with significant amounts of funds. But people around the mining area are still in poverty condition. The various challenges and obstacles in CSR implementation by mining companies in Indonesia are that the implementation of community development is only done solely to obtain local permits for the extraction of coal mines to achieve production targets and corporate revenue continues to increase.

\section{Literature Review}

\subsection{CSR in Development in Indonesia}

There is a debate about the definition and purpose of CSR. Most scholars argue that CSR is a blend of business ethics and philanthropic giving. Bowie (1990); Freeman (1994), (2003), Vogel (2005) Phillips and Margolis (1999), argue that CSR is a form of moral and ethical responsibility to business people. In this case, Bowie emphasizes that the company is a reflection of capitalist behavior that garnered the greatest advantage. The steps taken as a form of CSR is a form of moral concern to the community. So often the form of CSR done is a charity activity on clients, consumers, and society.

Friedman (1970) explicitly states that the social responsibility undertaken by the company is merely an attempt to profit as much as possible. ("The Social Responsibility Of Business Is To Its Increase Profits Written By Milton Friedman in The New York Times Magazine, September 13, 1970):" "Friedman, 1970 in www.colorado.edu)."

In practice, the implementation of CSR in Indonesia is confirmed by the Law of Limited Liability Company No.40 of 2007 , as well as for extractive companies such as mineral and coal mining there is Mineral and Coal Mining Act, stating that mining companies are obliged to care about the surrounding community. This concern is realized through community development and empowerment. It also causes CSR programs by mining industries in Indonesia to be synonymous with community development programs.

Community development is one of the alternatives in the implementation of CSR for mining companies in Indonesia. The basic idea of community development, in this case, seeks to release the dependence of the community on the company through the attachment inherent in the concept of empowerment is mentioned as the

most potential CSR form for mining companies, especially in Indonesia. Characteristics of people in developing countries are still left behind in development, while the many problems that exist not yet handled by the government at once. So the government demanded from the business world to contribute to the implementation of development.

The implementation of CSR ideally indeed cannot be separated from various challenges. Furthermore; in agreement with what is disclosed Frynas (2007), that the implementation of CSR faces challenges of development and governance, especially in efforts to harmonize corporate CSR goals with government development goals in the region where they operate. Implementation of CSR through community development program is an effort to face the international goals in which CSR is expected to support and achieve the target of a country. One of the primary goals is to reduce poverty. (Jenkins, 2005).

\subsection{Community Development and Community Empowerment in CSR}

Community development becomes necessary because the ministerial regulation governing CSR implementation clearly states the obligation to develop and empower communities by mining companies. Community development according to the United Nations in 1951 is defined as a process designed to create economic and social progress for all citizens with active participation and as far as possible to foster community initiative itself. So it can be understood that an essential prerequisite of community development is participation, in this definition community development is emphasized on social and economic issues. J.D.Mezirow in Sanders (1970:19) defines community 
development as a process; a planned and organized effort to support individuals in gaining the required attitudes, skills and concepts in participating in effective solutions for problem-solving.

Community development is an ideal method for addressing development impacts that are designed without involving the community, among others: (1) The low participation as a result of the demise of community initiatives in determining the purpose of life. Which is understandable because a development program designed, planned, and created by the government only puts the community as the object of development. (2) The low level of community participation due to some development programs that do not place the community as development actors in the sense of involving the community from the planning stage to the evaluation often cannot answer the needs of the community. Without engaging in determining the purpose of his life, people will be reluctant to contribute and depend on the company.

Ife (2006: 65) states the empowerment as follows: "The notion of empowerment is central to a social justice and human rights strategy." Empowerment is the most important principle in community development to achieve social justice and human rights. Community development programs in which there is empowerment will improve the ability of the community to meet the needs of life. According to Dharmawan (2000); empowerment is done to reduce the gap between communities and companies that can trigger a conflict that can ultimately hamper operations to achieve targets owned by the company. Empowerment is a process of having enough energy enabling people to expand their capabilities, to have greater bargaining power, to make their own decisions, and to access to a source of better living more easily.

The result of empowerment is an empowered community, and it can be seen that people have the power and opportunity to develop their lives based on their need and their own power independently. Empowering the community has a sense of putting people as subjects to improve their welfare and in the attempt to solve their problems.

The empowerment in this article is the expected result of the implementation of the community development program by the coal mining company. Ife (2006) mentions eight characteristics of a community that empowered can represent. The results of the CSR program are:

1. Power over individuals.

2. Power over resources,

3. Power over economic activity,

4. Power over the assertion of human rights,

5. Power over reproduction,

6. Control over the definition of need,

7. Power over the institution,

8. Power over the definition of need.

This characteristic is in accordance with what is sought by sustainable development, in which case a community that empowered will have the ability to improve the welfare of its life both when mining operations are still running or when the mining industry has stopped (life after mining). If it's not achieved then the goal of CSR through community development program can be said to fail.

Community development program as CSR implementation by coal mining company ideally is a reflection that the company has a desire to improve the welfare of community without causing dependency. Community empowerment is certainly not only the responsibility of the company but the responsibility of all parties, among others the government, the company (private sector) and the community itself.

\section{Methodology}

To describe implication of CSR implementation on community empowerment, a qualitative study was conducted. The profound significance of CSR's impact on a community is derived from informants' understanding of CSR implementation and its implications for empowerment (Ife, 2002). Data collection was conducted for eight months (January-August 2013) in Lawang Kidul SubDistrict, Muara Enim District of South Sumatra Province where PT. BARA is doing both mining operation and CSR activities.

The research begins with learning about community development program as CSR 
implementation conducted by coal mining company, through literature study (journal and research report on community development and CSR in Indonesia and other developing countries). This is done before the data collection process to understand the relation between phenomena with particular social perspective. The CSR perspective was adopted to enrich knowledge and analysis. The number of informants in this study is 27 people, consisting of CSR Manager and field officer from a company, program beneficiaries, local government, local leaders and community as common who know and engage in CSR program by PT. BARA.

Time reference for limit data collection based on the implementation of community development conducted by PT. BARA in 2010-2012. PT. BARA performs a CSR relying on the following policies:

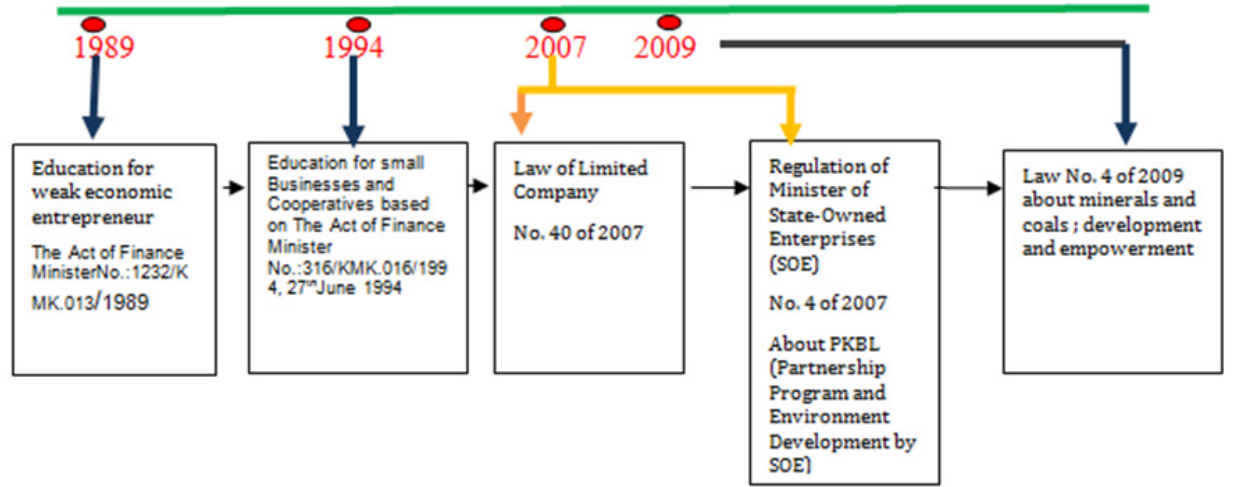

Picture 1. Time Reference for Research (2013)

\section{Implementation of CSR by Pt. Bara}

PT. BARA has conducted CSR since 1983. Board of Directors of PT. BARA mentioned that CSR is done to run the mining exploration process without any barriers. In addition to the economic motive as a driver of CSR implementation, PT. BARA aims to contribute to the improvement of people's quality of life. Board of Directors of PT. BARA thinks that with increasing public welfare they get a positive impact on mining process. In February 2013 there was a community demo because of unfair distribution of welfare. This demo causes delays in mining operations. Based on it PT. BARA drew up a policy for CSR to eliminate harassment that could hinder the achievement of targets; also a State-Owned Company PT. BARA must implement the Partnership Program and Community Development Program as the implementation of CSR.

\subsection{Program For Supporting Local Economy Improvement}

The Regulation of the Minister of State-Owned Enterprises, Per-05 / MBU / 2007 Article 1 Paragraph (6) explains that the company has to do Partnership and Community development Program as their CSR Implementation. Partnership program purposes to increase the capability of small-scale enterprises become vigorous and independent through the utilization of funds from their profit share.

This partnership becomes a standard program in the implementation of CSR by PT. BARA. This is primarily aimed at improving and developing the economy of the community. This partnership program is a program to support the community's economy by providing revolving capital assistance to small businesses, training grants, and promotional grants.

The development of SMEs that encourages the creation of new jobs for the community, in this case, has not emerged as an implication of the implementation of CSR. Moreover, it is found on the facts in the field that some of the beneficiaries (called partner) have not been in accordance with 
the primary objectives of the program itself. One type of business assisted in the field of capital through soft loans is a franchise business that in fact has an initial capital of hundreds of millions of rupiah while the maximum assistance for partners is a maximum of Fifty Million Rupiah (RP. $50.000 .000,00)$. Partnership Program is an empowerment effort that has consequences of activities that guide and protect UMKM to be able to face various challenges and obstacles in running its business. PT. BARA coaching is an effort of PT. BARA to provide capital assistance and opportunities for local SMEs with excellent products that have local characteristics to show in exhibitions such as internal bazaar and national exhibition.

One important part of the development is assistance. In this Partnership Program, there is support provided by field officer to the assisted partners. However, this assistance was not to be implemented intensively. One of the causes of the low intensity of assistance is the limited human resources in PT. BARA. The coverage area of PT. BARA is very wide covering 25 villages spread over four sub-districts. Thus, field officer as the program implementer can't do coaching to the partners one by one.

\subsection{Program To Improve Quality Of Community Life}

The Environmental Development Program is a large program that oversees some of the focus of activities, such as Education, Infrastructure, and Public Facilities/Infrastructure Development Program, Worship Improvement Program, Health Enhancement Program, Conservation Program and Disaster Relief Program. When viewed from the type of program undertaken, the Community Development Program has strived to meet the requirements of an integrated program (integrated development) seeks to meet several dimensions of development that is between economic growth and social development. Ife (2010:212) explains that an entire development needs to involve a holistic development aspect. Economic development does not rule out social needs.

The Minister Regulation of Owned State Company, Per-05 / MBU / 2007 Article 11 explains in detail that there are 6 (six) the main activities in the Community. Development program overall has the initial word "assistance" among others: natural disaster relief, educational assistance, or training, health promotion, infrastructure development assistance and/or public facilities. The types of programs that have been regulated through the Minister of State-Owned Enterprises make the partnership program in every owned state company in Indonesia.

The Community Development Program seeks to apply a "bottom-up" approach. CSR Program of PT. BARA is aligned with development planning at the district level. Starting from the deliberation of development planning at the lowest level is in the villages. Which means planning is done by government agencies, community and by business actors.

In implementing the Community Development program, PT. BARA seeks to involve relevant agencies in it so that the objectives of the program implementation can be achieved. Some stakeholders who involved are local governments, universities and contractors/consultants who have competence in the field of public facilities and infrastructure development.

PT. BARA opens the greatest opportunity to the community to convey the program idea that suits their needs in the form of a proposal. While in the implementation of the program, especially the development of public facilities and infrastructure derived from the "musrenbang" (local planning process) on the district, PT. BARA trusts and relies on consultants or third parties to undertake infrastructure development. The company policy does not open the opportunity for the public to become the leading actor in the project with a significant amount of money (above RP. $100,000,000$. /a hundred million rupiah) For the implementation of this program the community only becomes paid workers. Even though in several development programs such as improving religious facilities, making a siring site, repairing village hall, whose value is below RP. 100,000,000. (One hundred million rupiah) PT. BARA entrusted the management of the program on a self-managed basis to the community without involving the contractor.

Seeing from the process undertaken in the implementation of the program, this is in accordance with the characteristics of community development described by Batten (1967) in Adi (2013) as a directive approach, among which the community has the limitation to become an actor in the changes made for the achievement of their objectives. The company plays an important role 
for both decide or determine the direction of community change in accordance with the interests of the company itself.

Another program is a scholarship to students who came from low-income family. To get assistance, the school must submit a request proposal for scholarships to PT. BARA. Constraints that occur is not all schools that are in Ring-1 of PT. BARA is aware of the existence of the program and don't know how to access the program. Thus if a school does not submit a proposal to the company, then the school will not get help from PT. BARA. Prayogo (2011) describes the distributive of welfare in the conduct of mining operations, where the company has enormous power in various fields resulting in an enormous social-economy gap separating the company and society.

Environmental Development Program conducted by PT. BARA has been widely felt by the community both in quantity and benefits. The program of building public facilities and infrastructure becomes very dominant in the implementation of the program. The program is then claimed as a community development program. PT. BARA thinks infrastructure improvements will lead to improvements in people's quality of life. Thus the development of the community is understood as a synthetic form, and the development means as the construction of physical facilities and infrastructure.

This Program is adamant with the term "aid" causing the implementation of all types of activities is more closely to assistance than empowerment. In other words, the company is a party who help and community are the party who are assisted. Aiding party is considered to have a generous nature while the community is regarded as a powerless party. Even the activities undertaken refer to what the community asks. The main purpose of PT. BARA open to the aspirations of the community through the acceptance of the proposal is that the program is really something that the community needs so that the program will be designed to be a sustainable program.

Community development is actually a unity between program, process, method, and movement (Sanders, 1970). With the above understanding, it is known that all this time the company considers that the program conducted only a series of activities carried out systematically to meet the needs of the community without involving the process in more depth. Furthermore, the process of "community development" means how the people progress in quality and quantity, especially in attitude, skill, and initiative in understanding and solving existing problems (Sanders, 1970).

Actually in the CSR process that has been implemented so far PT. BARA has sought to cultivate initiatives under the existing openness principle, but the growth of this initiative is not accompanied by the growth of attitudes, understanding, and skills in solving problems. In fact what happens is that society becomes highly dependent on the company, this is marked by the emergence of the habit of asking the company for help on any new problems that arise. The community indirectly has no chance to determine his life due to the mindset that always wanted to be assisted.

\section{CSR Implications Pt. Bara on Community Empowerment}

\subsection{Empowerment in Determining the Purpose of Life}

Ife (2002) suggests that the ability to convey ideas or opinions is one of the characteristics of a powerful community. In this case, a capacity to convey ideas related to the tools, opportunities, and courage to express opinions or express ideas related to determining the purpose of life they want to achieve.

Empowerment in determining the purpose of life begins with the public awareness of the problems they face. The community who is living around PT. BARA has been able to define what they want in a proposal submitted to PT. BARA. The proposal then undergoes a series of the selection process on the CSR management of PT. BARA to assess whether the proposed activities in the proposal can be adopted as a CSR program.

In the process, it can be seen that community has no barriers in defining their needs. CSR Program PT. BARA has trained people to pour their ideas into a deliberation and then pour the idea 
into a proposal. When a proposal has been compiled it means the community has been able to think of the direction of change they want to achieve. But so far CSR process has not empowered the community to sort out where the needs and where the desire.

Because of the authority to decide the program is in the hands of PT. BARA, the ability to define the needs possessed by the community has not shown the ability to determine the purpose of life. The company regulates how the CSR program is done, and what kind of programs will be the CSR program of PT. BARA. Until now, people do not have the opportunity to choose their life goals in accordance with their needs and wants, the main factor that causes it to happen is still limited in accessing the source system of life and distribution of welfare that is still not evenly distributed.

\subsection{Institutional Inability to Access the Source System}

A powerful community can be seen from their ability to access the source system in their life. Some potential source systems are a source of education and health resources. In the CSR program in education, PT. BARA provides education facilities and infrastructure and school scholarships. Meanwhile, in the health program of PT. BARA conducts various incidental programs such as mass circumcision programs, assistance at community child services (called posyandu), eye treatment, and others.

Before the program is implemented, the community complaints about the difficulty in accessing health facilities and infrastructure, but PT. BARA built a public hospital as a solution. On the one hand, the community is greatly helped by the health assistance program from PT. BARA, but this assistance has not made the community into being able to access various resources within their capabilities. Incidental assistance, to the establishment of the Hospital, facilitates the community to access health institutions but does not alleviate the cost or improve the quality of public health.

The empowerment to access the source system resources especially the source system of education can be seen in the ability of the community to send their children to reach the level of basic education. While in the health sector, the capacity to access this source system can be seen at the level of health and environmental sanitation is good, as well as the ability of the community to access health services that exist in their region.

The people feel that there is still difficulty in accessing basic education services. Although there has been scholarship assistance from PT.BARA, there are still children who drop out, and the community has difficulty accessing senior high school. Similarly, health facilities are difficult to access because the Regional General Hospital has a very long distance from where they live. Meanwhile, community health center available in the vicinity of their residence have limitations in providing services such as limited medical personnel and inadequate health facilities and infrastructure.

This powerlessness is primarily an institutional disability, and the people cannot change their destiny to access the education and health service system because of the poverty and social security that should be the government's responsibility is not adequate. Ife (2013: 60) explains that the institutional perspective sees the inadequacy of the social security system causing poverty conditions in society, making it difficult for them to access health services, education, employment services, and so forth.

Such a complex problem is certainly difficult to be solved by CSR programs conducted by companies that incidentally have a "profit oriented" goal even in "social activity" that they do. But the opportunity to take part in community development and empowerment certainly exists. This can be achieved by synchronizing the company's CSR program with the government program. Besides, companies need to arouse the spirit of independence in the community to be able to solve problems they face without being dependent on the company. Because CSR patterns that have the connotation of "help" will create new challenges that worsen the situation, in examples the community becomes helpless after the company no longer operates. 


\subsection{Inequality of Empowerment in Conducting Economic Activities}

This empowerment means the ability of people to engage in economic activities that have an impact on increasing income to meet family needs. The Partnership Program has the purpose of strengthening SMEs to create new jobs. The purpose of PT. BARA is achieved by several partners who can run a good business. In some training grant programs, the community has stated that the Partnership Program has not been significantly affected. This can be seen from the fact that there are still many housewives who are in debt and can't do productive activities. But in reality, several partners have been able to market their products to supermarkets, even nationally. However, it seems that it is only casuistic, especially for partners who initially have been established for a long time and have a market share.

Capital assistance from PT. BARA, in the end, is an injection of additional funds. In other words the partnership program as a "supplement" instead of "medicine" to grow new partners who can open a business and able to absorb labor. Also, information on capital assistance for SMEs in Partnership Program as an effort to improve economic empowerment is not yet known by all layers of society, and access to this program becomes easier for SMEs who have proximity (element of neighbor or brother) with employees of PT. BARA.

Basically, capital (financial and relational resources) to build and print new reliable SMEs has been owned by PT. BARA, external policies that exist also support in the implementation of it. During this time the community has submitted various aid proposals that lead to increased economic activity. But the empowerment in doing economic activity has not been felt by the community. Society is still in the old mindset where the company is the best place for a career. Local economic development is still a trend and can't be relied upon by the community as a source to supplement income. This is because PT.BARA has not implemented a program plan that is really in accordance with the potential of the community, as well as in the implementation of existing planning human resources engaged in the field of CSR is not adequate.

Thus can be known CSR program PT. BARA both Partnership Program and Community Development Program are still at charity level so that the various character of powerless society does not seem to appear significantly as a result of CSR implementation of PT. BARA.

\section{Conclusion}

The leading actor in the implementation of CSR by state-owned companies in Indonesia in this article is still centered on the company. In the case of partnership and environmental development programs, the community tends to "know it done." The program has not been able to improve the community's capacity in determining life goals, increasing access to source systems, and increasing economic activity. With this pattern new problems will occur, will be born community's dependency on the company.

Actually, the community's independence has emerged, especially in the environmental development which self-management do community development as program implementation. But unfortunately, this pattern can't be done on all CSR programs because the company associated with internal and external rules. In this self-managed development, activity is also the condition of dependence, especially regarding capital. The community has not been able to access the source system other than the company.

CSR programs can't be said to develop and empower the community yet successfully. People's empowerment has arisen in the ability of individuals to devote ideas or thoughts and to determine their purpose in life. But the achievement still leaves another task of community's dependence. This condition is a big challenge for life after mining.

\section{References}

Adi, I. R. 2013. Community Development and Community Intervention. Jakarta: FE-Universitas Indonesia.

Bowie, Norman E. 1990. Money, Morality, and Motor Cars, In Business Ethics and the Environment, ed W. F. Hoffman, R. Frederick, and E.S. Petry, 89-97, New York: Quorum Books. 
Dharmawan, AryaHadi, 2000. Poverty Powerlessness, and Poor People Empowerment: Thinking Pece Derived from an Indonesian Case. Workshop on Rural Institutional Empowerment held in Indonesian (hall. 2). Jakarta: Consulate General of The Republic Indonesia.

Elkington, J. 1997. Cannibals with Forks: The Triple Bottom Line of 21st Century. Philadelphia: New Society. Evan, W.M.,\&Freeman, R.E.(1988).A stakeholder theory of the modern corporation: Kantian Capitalism.InT.Beauchamp\&N.Bowie(Eds.),Ethicaltheoryandbusiness(pp.75-93).EnglewoodCliffs, $\mathrm{NJ}$ :PrenticeHall.

Eweje.G. 2006. The Role of MNE's in Community Development Initiatives in Developing Countries. Sage Publication volume 45, 93-129.

Fallon, G. C. 2010. Giving With One Hand: On the Mining Sector's Treatment of Indigenous Stakeholders in the name of CSR. International Journal of Sociology and Social Policy vol 30, 666-682.

Fatah, L. 2008. The Impacts of Coal Mining on the Economy and Environment of South Kalimantan Province, Indonesia. Asean Economic Bulletin vol 25, 85-98.

Frank den Hond, F.G. 2007. Managing CSR in Action; Talking, Doing, and Measuring. England: Ashgate Publishing Limited.

Freeman, R.E. (1994).The politics of stakeholder theory: Some future directions. Business Ethics Quarterly, 4(4), 409-429.

Frynas, J. G. 2007. Beyond Corporate Social Responsibility. New York: Cambridge University Press

Hopkins, M. 2007. Corporate Social Responsibility \& International Development; Is Business The Solution?. United Kingdom: Earthscan.

Idemudia, U. 2009. Oil Extraction and Poverty Reduction in Niger Delta: A Critical Examination of Partnership Initiatives. Business Ethics, 90/91-116.

Ife, Jim., F. T. 2006. Community Development: Community-based alternatives in age of globalization. Melbourne: Longman.

Ife, Jim., 2013, Community Development In an Uncertain World: Vision, Analysis, and Practice, New York: Cambridge University

Jenkins, R. 2005. Globalization, Corporate Social Responsibility, and Poverty. International Affairs. Vol:80. No:03. Pp 524-40

Kapelus, P. 2002. Mining, Corporate Social Responsibility and the "Community": The Case of Rio Tinto, Richard Bay Minerals and the Mbonambi. Journal of Business Ethics, 275-296.

Kemp, J. R. 2012. Assets, Capitals, and Resources: Frameworks for Corporate Community Development in Mining. International Association for Business and Society, 382-408.

Ogula, D. C. 2008. Stakeholder Involvement In Corporate Social Strategy: An Ethnographic Study Of The Niger Delta, Nigeria. Phoenix: University Of Phoenix.

Phillips, Robert A., and Joshua D., Margolis, 1999, Toward an Ethics Organizations, Business Ethics Journal Quarterly, 9: 619-638.

Prayogo, D. 2011. Socially Responsible Corporation: PetaMasalah, Tanggung JawabSosialdan Pembangunan Komunitaspadalndustri Tambang dan Migas. Jakarta: UI Press.

PSE-UI (Pusat Studi Energy-Universitas Indonesia). Jakarta. 2002. Indonesia Energy Outlook \& Statistics 2000. UI-Press. Jakarta.

Sanders, I. T. (1970).The Concept of Community Development.on L. J. Cary, Community Development As a Process (page. 19). Columbia: University of Missouri Press.

Vogel, D. (2005). The Market for Virtue; The Potential and Limits of CSR. Washington DC: The Brookings Institution.

Yakoveleva, Natalie., Vasquez, Diego-Burst., 2012, Journal of Business Ethics Vol 106, No. 2 p.191. 